\title{
Community structure across a large-scale ocean productivity gradient: Marine bird assemblages of the Southern Indian Ocean
}

\author{
K. David Hyrenbach ${ }^{\mathrm{a}, *, 1}$, Richard R. Veit ${ }^{\mathrm{b}}$, Henri Weimerskirch ${ }^{\mathrm{c}}$, \\ Nicolas Metzl ${ }^{\mathrm{d}}$, George L. Hunt Jr. ${ }^{\mathrm{e}, 1}$ \\ ${ }^{a}$ Duke University Marine Laboratory, 135 Duke Marine Laboratory Road, Beaufort, NC 28517, USA \\ ${ }^{\mathrm{b}}$ Department of Biology, CSI-CUNY, 2800 Victory Boulevard, Staten Island, NY 10314, USA \\ ${ }^{\mathrm{c} C e n t r e ~ d ' E t u d e s ~ B i o l o g i q u e s ~ d e ~ C h i z e ́, ~ C e n t r e ~ N a t i o n a l e ~ R e c h e r c h e ~ S c i e n t i f i q u e, ~} 79360$ Villiers en Bois, France \\ ${ }^{\mathrm{d}}$ LOCEAN-IPSL, Université Pierre et Marie Curie, Case 100, 4 place Jussieu, 75252 Paris, France \\ ${ }^{\mathrm{e}}$ Department of Ecology and Evolutionary Biology, 465 SH (Mail Code 2525), University of California Irvine, Irvine, CA 92697, USA
}

Received 6 July 2005; received in revised form 30 April 2007; accepted 2 May 2007

Available online 22 May 2007

\begin{abstract}
Our objective was to understand how marine birds respond to oceanographic variability across the Southern Indian Ocean using data collected during an 16-day cruise (4-21 January 2003). We quantified concurrent water mass distributions, ocean productivity patterns, and seabird distributions across a heterogeneous pelagic ecosystem from subtropical to sub-Antarctic waters. We surveyed $5155 \mathrm{~km}$ and sighted 15,606 birds from 51 species, and used these data to investigate how seabirds respond to spatial variability in the structure and productivity of the ocean. We addressed two spatial scales: the structure of seabird communities across macro-mega scale (1000 s km) biogeographic domains, and their coarse-scale $(10 \mathrm{skm})$ aggregation at hydrographic and bathymetric gradients. Both seabird density and species composition changed with latitudinal and onshore-offshore gradients in depth, water temperature, and chlorophyll-a concentration. The average seabird density increased across the subtropical convergence (STC) from 2.4 birds km $^{-2}$ in subtropical waters to 23.8 birds km${ }^{-2}$ in sub-Antarctic waters. The composition of the avifauna also differed across biogeographic domains. Prions (Pachyptila spp.) accounted for 57\% of all sub-Antarctic birds, wedge-tailed shearwaters (Puffinus pacificus) accounted for $46 \%$ of all subtropical birds, and Indian Ocean yellow-nosed albatross (Thallasarche carteri) accounted for $32 \%$ of all birds in the STC. While surface feeders were the most abundant foraging guild across the study area, divers were disproportionately more numerous in the sub-Antarctic domain, and plungers were disproportionately more abundant in subtropical waters. Seabird densities were also higher within shallow shelf-slope regions, especially in sub-Antarctic waters, where large numbers of breeding seabirds concentrated. However, we did not find elevated seabird densities along the STC, suggesting that this broad frontal region is not a site of enhanced aggregation.
\end{abstract}

(C) 2007 Elsevier Ltd. All rights reserved.

Keywords: Community structure; Seabirds; Ocean productivity; Oceanic fronts; Remote sensing; Species assemblages; Crozet Basin; Indian Ocean

\footnotetext{
*Corresponding author.

E-mail address: khyrenba@duke.edu (K.D. Hyrenbach).

${ }^{1}$ Present address: School of Aquatic and Fishery Sciences, University of Washington, Box 355020, Seattle, WA 98195, USA.
} 


\section{Introduction}

Oceanic species distributions are influenced by physical and biological variability over multiple spatio-temporal scales (Haury et al., 1978; Hunt and Schneider, 1987). Over large (meso-mega, $100 \mathrm{~s}$ to $1000 \mathrm{skm}$ ) spatial scales, the ranges of large predatory fishes, marine birds, mammals, and turtles mirror oceanographic domains and current systems (Griffiths et al., 1982; Sund et al., 1981; Tynan, 1998; Polovina et al., 2004). Smaller-scale (coarse, $10 \mathrm{~s} \mathrm{~km}$ ) physical processes enhance localized ocean productivity and concentrate nektonic predators and their prey at hydrographic (e.g., fronts) and bathymetric (e.g., shelf-slope) features (Franks, 1992; Hunt et al., 1999; van Franeker et al., 2002).

The southern Indian Ocean $\left(20-60^{\circ} \mathrm{S}\right)$ is characterized by strong latitudinal gradients in physical, chemical, and biological properties (Metzl et al., 1991; Park et al., 1993; Park and Gambéroni, 1995; Fiala et al., 2003). A major oceanographic feature in this region is the subtropical convergence (STC), a broad $(\sim 100 \mathrm{~km})$ frontal region separating warm and salty subtropical waters to the north, from cold and fresh sub-Antarctic waters to the south (Park et al., 1993, 2002; Park and Gambéroni, 1995; Kostianoy et al., 2004). Between $30^{\circ} \mathrm{S}$ and $45^{\circ} \mathrm{S}$, surface waters are brought together by the prevalent wind patterns, thereby creating a zone of enhanced surface gradients (Lutjeharms, 1985; Furuya et al., 1986; Park and Gambéroni, 1995; Rio and Hernández, 2003). The STC is recognizable by a strong latitudinal decline in water temperature (sea-surface temperature (SST)) of $\sim 7^{\circ} \mathrm{C}$ (summer: $18-10^{\circ} \mathrm{C}$, winter: $15-8{ }^{\circ} \mathrm{C}$ ), concurrent with a drop in salinity, and an increase in nitrate and phosphate (Lutjeharms et al., 1985; Longhurst, 1998). This permanent frontal zone delineates three biogeographic provinces with distinct physical and biological properties: the south subtropical convergence (SSTC), the Indian south subtropical gyre (ISSG) to the north, and the sub-Antarctic water ring (SAWR) to the south (Longhurst, 1998).

This study focuses on marine birds because these numerous and conspicuous predators respond to spatial and temporal oceanographic variability across the southern Indian Ocean (Pocklington, 1979; Stahl et al., 1985; Inchausti et al., 2003; Pinaud et al., 2005). We hypothesized that the marine avifauna of the Southern Indian Ocean is structured by the large-scale latitudinal gradients in hydrographic properties and ocean productivity patterns described above. The objectives of this study are to (1) characterize spatial patterns of seabird density across a large and heterogeneous oceanic ecosystem; and (2) determine whether distinct seabird assemblages inhabit specific ocean domains defined by distinct physical (e.g., bathymetry, SST) and biological (e.g., chlorophyll-a, productivity) properties. To quantify differences in seabird density and community structure across large biogeographic domains, we also had to consider small-scale spatial variability (e.g., fronts, shelves-slopes). Thus, our analysis addresses seabird aggregation at coarse-scale $(\sim 10 \mathrm{~s} \mathrm{~km})$ bathymetric and hydrographic features, as well as mega-macro scale $(\sim 1000 \mathrm{~s} \mathrm{~km})$ dispersion patterns.

\section{Methods}

\subsection{Study area}

We sailed on an 18-day (4-21 January 2003) cruise from La Réunion $\left(21^{\circ} 06^{\prime} \mathrm{S} ; 55^{\circ} 6^{\prime} \mathrm{E}\right)$, visited the French sub-Antarctic territories of Crozet $\left(46^{\circ} 30^{\prime} \mathrm{S}\right.$; $\left.51^{\circ} 00^{\prime} \mathrm{E}\right)$, Kerguelen $\left(49^{\circ} 30^{\prime} \mathrm{S} ; 6^{\circ} 30^{\prime} \mathrm{E}\right)$, St. Paul $\left(38^{\circ} 43^{\prime} \mathrm{S} ; \quad 77^{\circ} 29^{\prime} \mathrm{E}\right)$, and Amsterdam (37 $52^{\prime} \mathrm{S}$; $\left.77^{\circ} 32^{\prime} \mathrm{E}\right)$, and finished in Perth, Western Australia $\left(32^{\circ} 01^{\prime} \mathrm{S} ; 115^{\circ} 47^{\prime} \mathrm{E}\right)$. This cruise track, from subtropical to sub-Antarctic waters, allowed us to examine the avifauna within three biogeographic domains with distinct physical and biological characteristics (Fig. 1, Table 1). La Réunion, Mauritius, Crozet, Kerguelen, St. Paul, Amsterdam, and Western Australia are the main seabird breeding grounds in this region (Appendix A).

\subsection{Oceanographic data sets}

Five major frontal systems occur within the study area (Fig. 1). Because these fronts are delineated by surface and sub-surface $(200 \mathrm{~m}$ depth) signatures, we used satellite data (Fig. 2E and F) and water temperature profiles (Fig. 3) to characterize the hydrography of the study area (Park et al., 1993; Moore et al., 1999; Park et al., 2002; Kostianoy et al., 2004).

We relied on monthly composites (January 2003) of satellite remote sensing to characterize twodimensional water properties and gradients along the cruise track. These data provided SST and chlorophyll-a concentration (CHL) measurements for $97.5 \%(548 / 562)$ of the 9-km track-line bins we surveyed (Fig. 2E and F). 


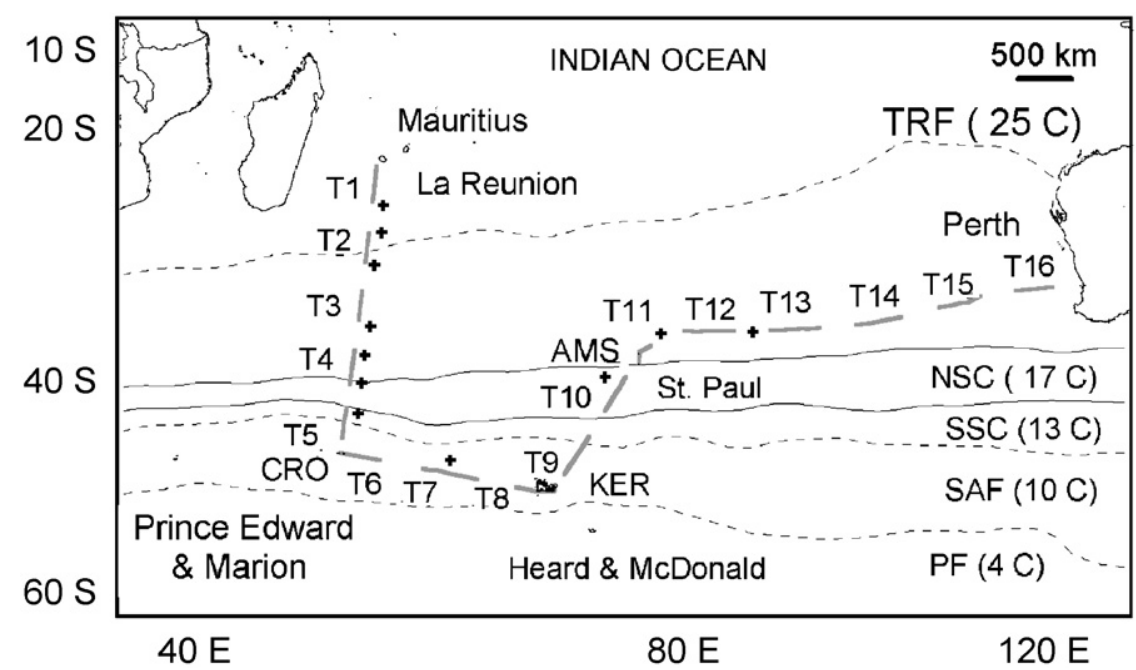

Fig. 1. Map of the southern Indian Ocean, showing the survey track (grey lines) and the islands visited during the cruise (AMS: Amsterdam, CRO: Crozet, KER: Kerguelen), superimposed over the major frontal systems delineated by sea-surface isotherms $\left( \pm 1^{\circ} \mathrm{C}\right)$ : Tropical Front (TRF, $25^{\circ} \mathrm{C}$ ), northern extent of the Subtropical Convergence (NSC, $17^{\circ} \mathrm{C}$ ), southern extent of the Subtropical Convergence $\left(\mathrm{SSC}, 13^{\circ} \mathrm{C}\right)$, Sub-Antarctic Front $\left(\mathrm{SAF}, 10^{\circ} \mathrm{C}\right)$, and Polar Front $\left(\mathrm{PF}, 4^{\circ} \mathrm{C}\right)$. The SST data were obtained by averaging three weekly composites of the Reynolds Optimally Interpolated data set (PODAAC product \#19), with a spatial resolution of $1 \times 1{ }^{\circ}$ latitude/ longitude (http://poet.jpl.nasa.gov/). The locations of 16 daily transects (T) and 11 pairs of Argo float profiles $(+)$ are shown.

Table 1

Indicators of ocean productivity in different biogeographic domains across the southern Indian Ocean. The physical climatologies are based on long-term (1945-1996) average monthly sea-surface temperature (SST) and mixed layer depth (MLD) for January $\left(1 \times 1{ }^{\circ}\right.$ latitude/longitude) (Boyer et al., 1998) from the World Ocean Database (WOA, http://www.pfeg.noaa.gov/)

\begin{tabular}{|c|c|c|c|c|}
\hline & & Subtropical (ISSG) & Convergence (SSTC) & Sub-Antarctic (SAWR) \\
\hline \multirow[t]{2}{*}{ Extent } & SST range $\left({ }^{\circ} \mathrm{C}\right)$ & $>17$ & $13-17$ & $<13$ \\
\hline & Latitude range $\left({ }^{\circ} \mathrm{S}\right)$ & $21.82-40.47$ & $36.00-42.83$ & $42.560-49.753$ \\
\hline \multirow[t]{2}{*}{ Sample size } & Survey effort $\left(\mathrm{km}^{2}\right)$ & 815.4 & 221.4 & 442.8 \\
\hline & Survey bins (\#) & 302 & 82 & 164 \\
\hline Abundance & $\mathrm{CHL}\left(\mathrm{mg} \mathrm{m}^{-3}\right)$ & $0.13(63.62)$ & $0.26(27.66)$ & $0.28(65.22)$ \\
\hline Mean (C.V.) & Birds $\left(\# \mathrm{~km}^{-2}\right)$ & $2.38(526.67)$ & $2.38(105.84)$ & $23.83(250.41)$ \\
\hline Seabird feeding guilds & Divers $(\%)$ & $3.8(7.1)$ & $5.5(14.3)$ & $6.7(25.0)$ \\
\hline \multirow[t]{2}{*}{ Individuals (species) } & Plungers $(\%)$ & $15.7(10.7)$ & $0.8(3.6)$ & $0.0(0.0)$ \\
\hline & Surface feeders $(\%)$ & $80.5(82.1)$ & $93.7(82.1)$ & $93.3(75.0)$ \\
\hline Climatology & Latitude $\left({ }^{\circ} \mathrm{S}\right)$ & $22-36$ & $36-43$ & $43-50$ \\
\hline \multirow[t]{4}{*}{ Mean \pm S.D. (sample size) } & WOA 1998 SST $\left({ }^{\circ} \mathrm{C}\right)$ & $23.53 \pm 2.11$ & $16.96 \pm 2.55(145)$ & $8.12 \pm 3.22(88)$ \\
\hline & WOA 1998 MLD (m) & $40.67 \pm 26.40(115)$ & $47.29 \pm 44.72(68)$ & $81.91 \pm 41.25(55)$ \\
\hline & Chl-a concentration $\left(\mathrm{mg} \mathrm{m}^{-3}\right)$ & $0.06 \pm 0.02$ & $0.24 \pm 0.10$ & $0.29 \pm 0.19$ \\
\hline & Primary productivity $\left(\mathrm{g} \mathrm{C} \mathrm{m}^{-2}\right.$ year $\left.^{-1}\right)$ & $55.01 \pm 28.02$ & $152.61 \pm 105.13$ & $244.09 \pm 133.52$ \\
\hline
\end{tabular}

MLD is defined as the depth at which the density difference from the sea surface is $0.125 \delta$ units, and calculated using temperature/salinity data at 19 standard depths $(0-1000 \mathrm{~m})$ (Monterey and Levitus, 1997). The biological climatologies are based on MODIS (moderate resolution imaging spectroradiometer) primary productivity (Esaias, 1996) and chlorophyll-a concentration (CHL) (Hoge et al., 2003) data from January (2002-2003), with an 8-day and 36-km resolution.

We used Pathfinder SST data from the advanced very high resolution radiometer (AVHRR), with a spatial resolution of $9 \mathrm{~km}$ (Reynolds and Smith, 1994), which are available from the Jet Propulsion Laboratory (JPL) (http://podaac.jpl.nasa.gov/pub/ sea_surface_temperature/avhrr/pathfinder/datav4.1/), have been used previously to map SST fronts in the study area (Park et al., 2002; Kostianoy et al., 2004). Because we encountered a wide range of wind speeds (3.7-91.1 $\mathrm{km} \mathrm{h}^{-1}$ ) during our cruise (Fig. 2C), 
A

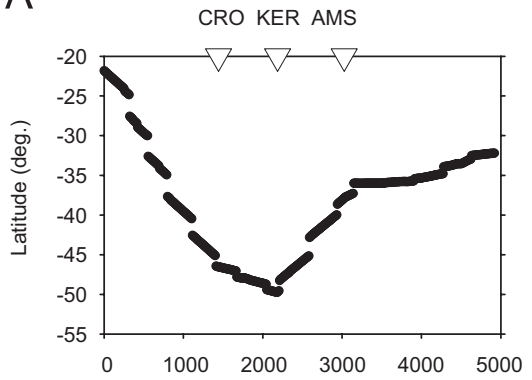

B

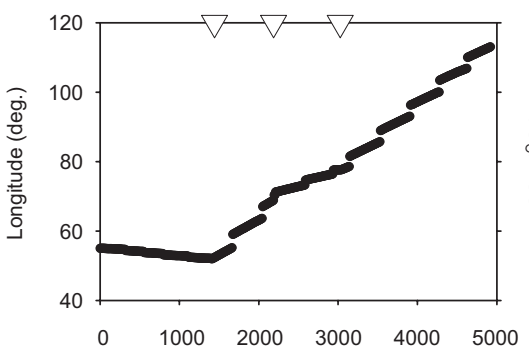

C

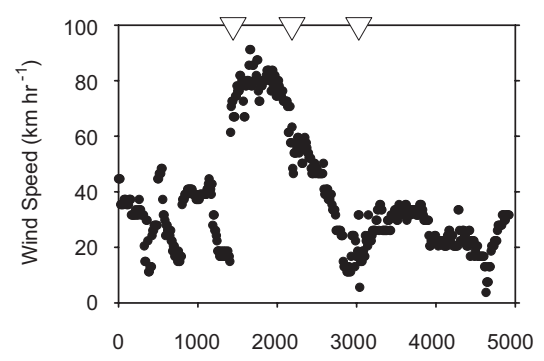

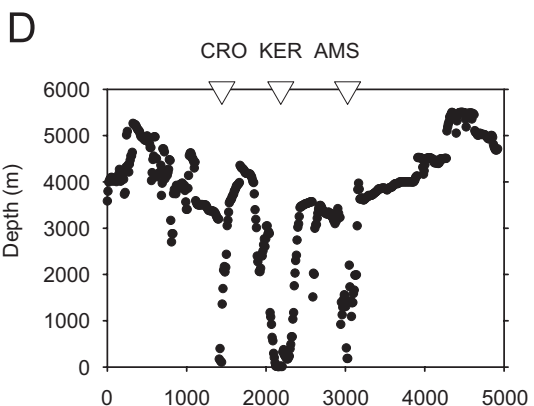

G

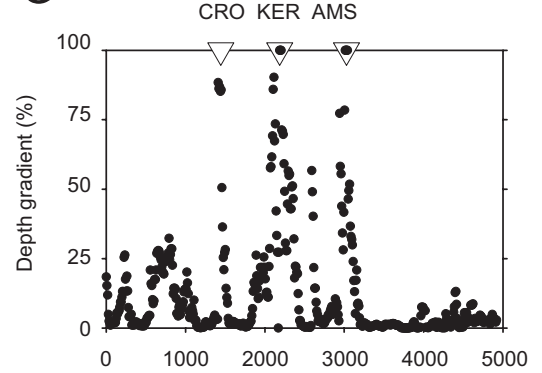

$\mathrm{H}$

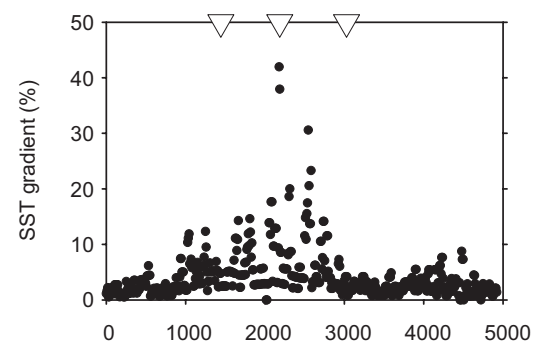

$\mathrm{F}$

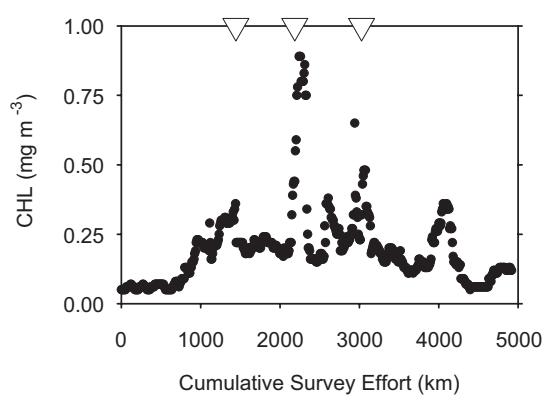

I

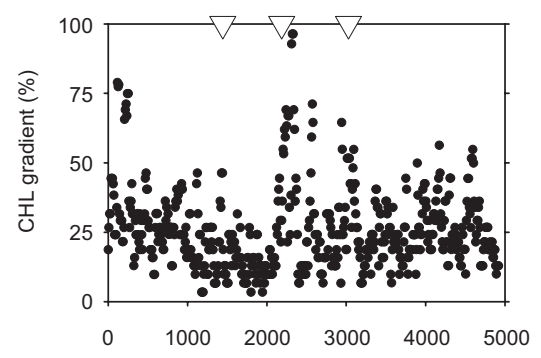

Fig. 2. Spatial distribution of (A) latitude, (B) longitude, (C) wind speed, (D) water depth, (E) sea-surface temperature (SST), (F) chlorophyll-a concentration (CHL), (G) depth gradients, (H) SST gradients, (I) CHL gradients at 548 9-km survey bins along the survey track. The inverted triangles indicate the location of the islands of Crozet (CRO), Kerguelen (KER), and Amsterdam (AMS).

we used nocturnal data exclusively to avoid SST biases due to unequal ocean surface heating and cooling. When compared to concurrent in situ World Ocean Atlas (WOA 98) observations, the nighttime Pathfinder SST data show a consistent negative bias $\left(-0.15^{\circ} \mathrm{C}\right)$ (Casey, 2002).

We derived the CHL along the cruise track from Sea-viewing Wide Field-of-view Sensor (SeaWiFS) data, with a spatial resolution of $9 \mathrm{~km}$ (http:// seawifs.gsfc.nasa.gov/SEAWIFS.html). Because SeaWiFS estimates are within $35 \%$ of in situ measurements within the range $0.05-50 \mathrm{mg} \mathrm{m}^{-3}$, we discarded high CHL values beyond this range of validation $\left(>50 \mathrm{mg} \mathrm{m}^{-3}\right.$ ) (Hooker and McClain, 2000).

To characterize the water column (0-200 m depth) temperature structure within the study area (Figs. 1 and 3), we used 22 concurrent (January 6-24, 2003) profiles from autonomous Argo floats. These floats provide temperature measurements with a resolution of $0.01{ }^{\circ} \mathrm{C}$ between the surface and the parking depth $(2000 \mathrm{~m})$ at 10-day intervals (Roemmich et al., 2004), and are publicly available at the Argo web-page (http://www.ifremer.fr/coriolis/cdc). The monthly Pathfinder SST data and the 5-m water temperature data from the Argo floats were significantly correlated (Pearson correlation, $r=0.93$; $n=22, \quad p<0.001)$, suggesting that the satellite composites accurately reflected the daily in situ water temperatures.

\subsection{Seabird surveys}

Depending on weather conditions, two of us (KDH, RRV) surveyed marine birds from the flying 

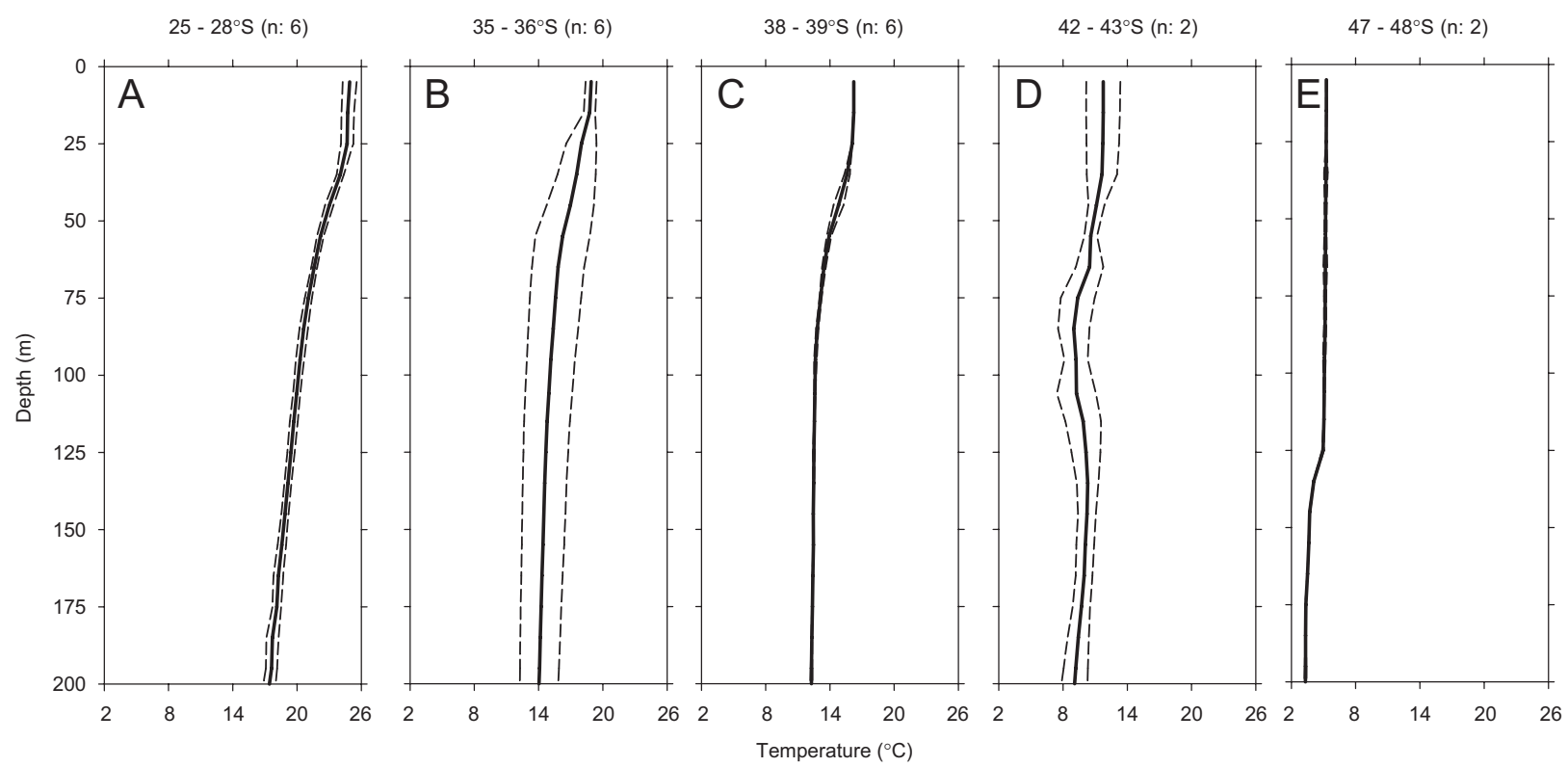

Fig. 3. Profiles of sub-surface $(0-200 \mathrm{~m}$ depth) water temperature within five latitudinal bands, showing the mean (solid line) \pm S.D. (hatched lines) values every $10 \mathrm{~m}$ depth.

bridge ( $26 \mathrm{~m}$ eye height) or from the pilot house (24 m eye height) of the R.V. Marion Dufresne. We surveyed seabirds during daylight hours, while the vessel cruised at speeds between 10 and 15 knots $\left(18.5-27.7 \mathrm{~km} \mathrm{~h}^{-1}\right)$, following standardized strip transect methods, which require that the designated survey strip-width is accurately maintained; and that all of the birds within the survey strip are detected (van Franeker, 1994). However, we did not use discrete equally spaced (e.g., $10 \mathrm{~min}$ ) "instantaneous" snapshots or the "vector" correction to account for bird movement. We identified all birds sighted within $300 \mathrm{~m}$ of the one side of the vessel with best visibility (e.g., least sun glare or wind) to the lowest possible taxonomic level and logged this information continuously into a computer with a temporal resolution of $0.1 \mathrm{~min}$. We noted the behavior (sitting, flying, feeding, ship following) of each bird, and ignored ship-followers after they had been first recorded. Thus, our observations likely included birds which were commuting between feeding and breeding grounds, and were not actually foraging in the ocean habitats where they were sighted. We also recorded wind speed $\left(\mathrm{km} \mathrm{h}^{-1}\right)$ from the ship's weather log and estimated Beaufort sea state and swell height (m) hourly, and whenever weather conditions changed appreciably.

\subsection{Seabird habitats}

We characterized seabird habitats using (1) wind speed, (2) SST, (3) SST gradients, (4) CHL, (5) CHL gradients, (6) depth, (7) depth gradients, (8) latitude, and (9) longitude.

Wind speed is an important determinant of marine bird distributions. Over large scales $(1000 \mathrm{~s} \mathrm{~km})$, species with distinct wing morphologies (e.g., aspect ratio, wing loading) preferentially inhabit regions of high and low winds (Spear and Ainley, 1998). Over smaller scales (10 s to $100 \mathrm{~s} \mathrm{~km}$ ), weather systems influence the ranging behavior and the activity patterns of foraging birds (Weimerskirch et al., 2000; Spruzen and Woehler, 2002). Because wind speed also impacts the ability to detect birds at sea (Dixon, 1977; Duffy, 1983), we included this variable in our analyses to account for potential survey biases.

Remotely sensed SST and CHL are useful proxies of water mass distributions and ocean productivity domains, and have been previously used to characterize seabird habitats across the southern Indian Ocean (Lutjeharms et al., 1985; Park et al., 2002; Weimerskirch et al., 2004; Pinaud et al., 2005).

Water depth also influences seabird distributions, as indicated by the disparate avifauna of coastal and oceanic domains (Schneider, 1997). In particular, 
shallow water is a proxy for productive coastal areas and continental shelves. We characterized the bathymetry along the cruise track using the National Geophysical Data Center ETOPO 5-min $\left(5.9-8.5 \mathrm{~km}\right.$ at $22^{\circ} \mathrm{S}$ and $50^{\circ} \mathrm{S}$ latitude, respectively) data set (NGDC, 1998).

In addition to calculating the mean SST, CHL, and depth along the cruise track, we quantified spatial gradients in these properties. For each $9-\mathrm{km}$ survey bin, we calculated the proportional change in these variables within a surrounding $3 \times 3$ pixel $\left(27 \times 27 \mathrm{~km}^{2}\right)$ grid, as follows: P.C.: [(maximum/ minimum $) \times 100] /($ maximum $)$. This dimensionless metric expresses the relative change in the habitat variable, scaled to the maximum value within the scale of analysis ( 9 pixels). Thus, $\mathrm{PC}$ ranges between $0 \%$ and $100 \%$ (Hui, 1985).

The distance to breeding colonies is an important determinant of seabird distributions in the southern Indian Ocean (Stahl et al., 1985; Jaquemet et al., 2004). Thus, we incorporated the effect of geographic location in our analyses to account for the constrained foraging ranges of breeding birds. However, rather than calculating the distance of each survey bin to the major seabird colonies in the region, we used the actual bin locations (latitude/longitude) as explanatory variables in our models.

\subsection{Spatial scales of analysis}

We performed our analyses using data at three spatial scales. First, we used the 9-km survey bins to characterize seabird density and community composition over coarse $(10 \mathrm{~s} \mathrm{~km})$ spatial scales. Second, we combined adjacent $9-\mathrm{km}$ survey bins into 16 disjunct meso-scale $(100 \mathrm{~s} \mathrm{~km})$ transects (mean length: $310 \pm 54$ S.D., range: $207-378 \mathrm{~km}$ ) separated by nighttime periods with no survey effort (Fig. 1). We combined the bird sightings within these daily transects and quantified the environmental conditions using the median and the coefficient of variation (C.V.: S.D./mean) of the individual $9-\mathrm{km}$ survey bins. The median is less sensitive to outliers than the average, and the C.V. quantifies the variability across survey bins scaled by the average value along an entire transect (Zar, 1984). Third, we aggregated the 9-km survey bins on the basis of their SST characteristics, and quantified seabird community structure within three large-scale biographic domains (Table 1): the STC, subtropical waters to the north, and sub-Antarctic waters to the south (Park and Gambéroni, 1995; Longhurst, 1998; Park et al., 2002; Kostianoy et al., 2004).

\subsection{Seabird abundance}

To account for the lack of normality in the seabird density data (one-sample KolmogorovSmirnov test, max_diff: $0.402, p<0.001, n$ : 548 bins), we performed the GLMs using log transformed data (Zar, 1984). The $y^{\prime}: \log (y+0.1)$ data transformation re-coded the minimum (0.00) and maximum (515.56) observed bird densities as -1.00 and 2.71 .

Before we performed our analyses, we quantified the autocorrelation of the bird density data to determine whether the 9-km survey bins were independent sampling units (e.g., van Franeker et al., 2002). We quantified the similarity of the log-transformed density data from adjacent survey bins using the Moran's I statistic, which ranges from +1 (similar counts) to -1 (dissimilar counts), with the expected value approaching 0 in the absence of autocorrelation (Sokal, 1978). Because our observations included $\mathrm{N}-\mathrm{S}$ and $\mathrm{E}-\mathrm{W}$ transects of different lengths, we did not assume isotropic autocorrelation patterns, and limited our analyses to a lag of 1 bin $(9 \mathrm{~km})$. We computed the Moran's I statistic using the Rookcase Excel Add-In software, with the rook adjacency rule (Sawada, 1999; Yen et al., 2004).

We related seabird density (number $\mathrm{km}^{-2}$ ) to concurrent environmental variables using general linear models (GLMs) and generalized additive models (GAMs). Because the environmental conditions along the survey track were cross-correlated (Table 2A), we used multi-variate GLMs to assess the relative influence of each variable on seabird density.

First, we assembled the best-fit GLM model iteratively using a step-wise procedure, by rejecting/ retaining the variables with the lowest/highest explanatory power one at a time. Then, we investigated the response of seabird density to each individual significant variable separately using GAMs and the Poisson link function. GAMs have been previously used to model the habitats of patchy oceanic organisms, because they offer a flexible non-linear modeling framework (Guisan et al., 2002; Clarke et al., 2003).

\subsection{Seabird community structure}

The simplest way to characterize a biotic community is to quantify the number and identity of the constituent species. To avoid mis-identifications, we 
K.D. Hyrenbach et al. / Deep-Sea Research I 54 (2007) 1129-1145

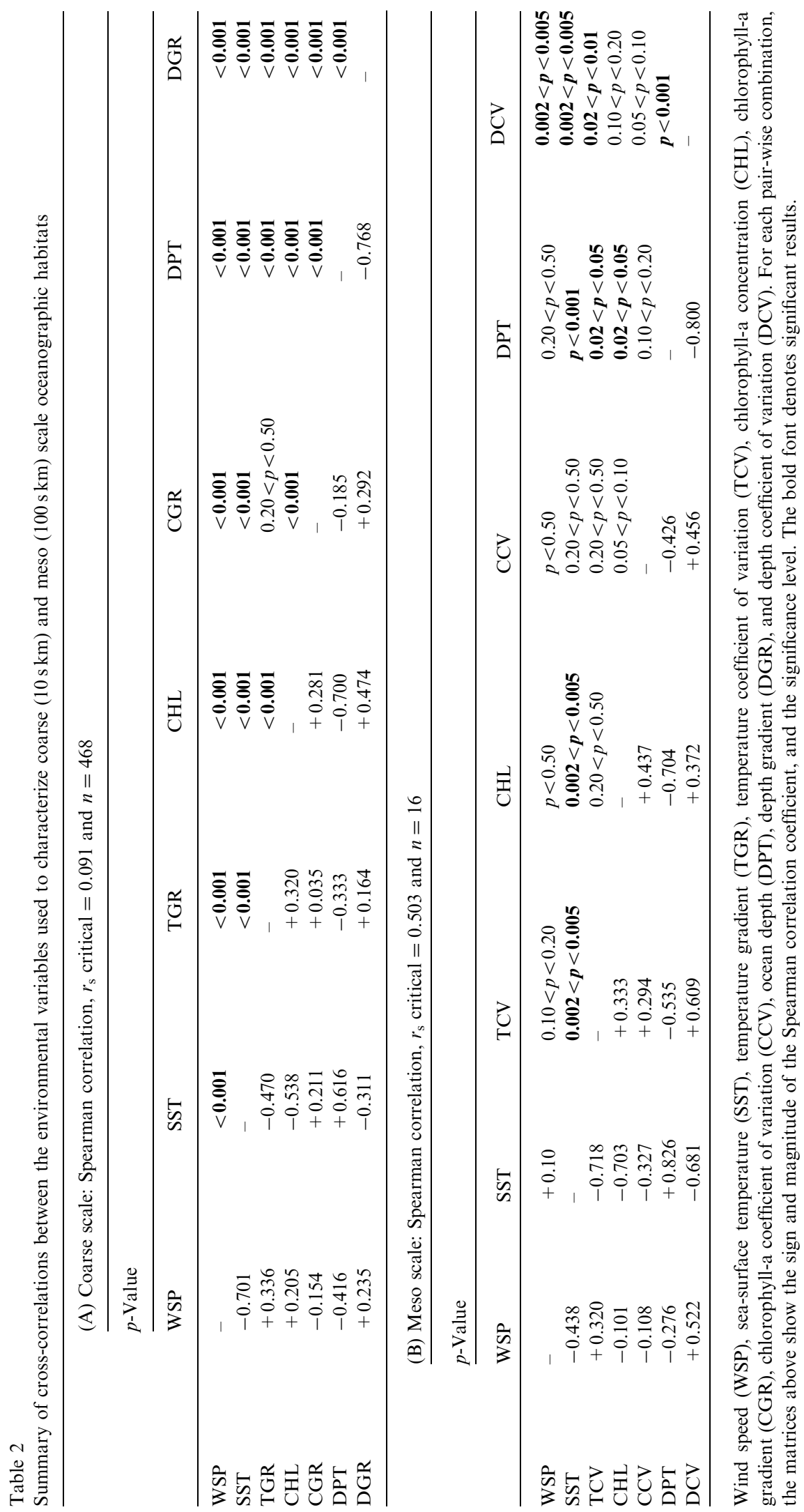


combined the counts of several closely related species that are difficult to identify at sea (e.g., van Franeker et al., 2002). Because over $98 \%$ of the prions (Pachyptila spp.) sighted were not identified to species, we pooled the counts of unidentified, thin-billed $(P$. belcheri), Salvin's $(P$. vittata salvini), fairy ( $P$. turtur), and dove $(P$. desolata) prions. We also combined the sightings of unidentified, South Georgian (Pelecanoides georgicus), and common (Pelecanoides urinatrix) diving petrels because the unidentified category accounted for $>98 \%$ of the birds sighted. Finally, we merged sooty (Sterna fuscata), bridled (Sterna anaethetus), and dark (S. fuscata/S. anaethetus) terns, which accounted for $67 \%, 1 \%$, and $32 \%$ of dark-colored tern sightings, respectively, into what we termed 'dark terns (DKTE)'. After pooling these sightings and discarding the remaining unidentified birds $(0.78 \%)$, our data set comprised 15,492 individuals and 46 taxa.

We used PC ORD's non-parametric multi-dimensional scaling (NMDS) approach to identify species assemblages, and to quantify the association between seabird distributions and the environmental variables described above (McCune and Mefford, 1999). NMDS is ideal for characterizing the habitats of patchy organisms because it does not impose any assumptions on the shape of the underlying habitat-wildlife relationships. Furthermore, NMDS does not assemble discrete groupings of species or samples, but plots them along a multi-dimensional continuum representing combinations of the explanatory variables. Species and samples from similar habitats are plotted closer (Kenkel and Orloci, 1986).

We selected an observation day as the sampling unit for the community-level analysis because we regarded the daily transects as discrete independent samples, separated by nighttime periods with no survey effort. Thus, our sample size was a matrix of 16 transects and 46 taxa (Appendix A). Because the survey effort $\left(\mathrm{km}^{2}\right)$ and the number of birds sighted varied from day to day, we standardized the samples by calculating the relative abundance (proportion of total seabird density) of the different taxa. To ensure each daily sample was weighted equally in the analysis, we used the relative Sorensen (BrayCurtis) index to calculate the pair-wise dissimilarity matrix between all daily transects (Manly, 1994).

\subsection{Biogeographic domains}

To address large-scale biogeographic patterns, we aggregated the 9-km survey bins into three non-overlapping domains, defined by SST characteristics: the warm waters $\left(\mathrm{SST}>17^{\circ} \mathrm{C}\right)$ of the ISSG, the SSTC (SST: $13-17^{\circ} \mathrm{C}$ ), and the cool waters $\left(\mathrm{SST}<13^{\circ} \mathrm{C}\right)$ of the SAWR (Longhurst, 1998). We summarized the environmental conditions and the characteristics of the avifauna within each domain, using three metrics: the satellitederived rate of primary production, CHL from satellites, and seabird density (Table 1). We also characterized the composition of the avifauna in each domain by quantifying the contribution of different foraging guilds: surface feeders (seizing, dipping, pattering, surface dive, aerial pursuit, hydroplaning, foot paddling), divers (pursuit dive, pursuit plunge), and plungers (surface, shallow and deep plunge) (Harper et al., 1985; Spear and Ainley, 1997, 1998). We compared the proportion of species and birds of these three guilds we encountered within each oceanographic domain using $G$ tests (Zar, 1984).

\section{Results}

\subsection{Oceanographic observations}

Our cruise track spanned subtropical to subAntarctic waters, and crossed four frontal systems (Fig. 1). During the southward transect from La Réunion to the Crozet Basin, wind speed increased (Fig. 2C), SST declined (Fig. 2E), and CHL increased above $0.2 \mu \mathrm{g} \mathrm{Chl} \mathrm{m}^{-3}$ (Fig. 2F). These conditions reversed during the northward transect from Kerguelen to St. Paul Island. We sailed through subtropical water $\left(18-20^{\circ} \mathrm{C}\right)$ east of Amsterdam Island, and encountered the warmer SSTs $\left(20-22{ }^{\circ} \mathrm{C}\right)$ characteristic of the Leeuwin Current off Western Australia (116-114 ${ }^{\circ} \mathrm{E}$ ) (Cresswell and Peterson, 1993; Surman and Wooller, 2000).

The vertical temperature profiles from the Argo floats confirmed our SST-based classifications of different water masses (Fig. 3). Subtropical regions $\left(25-28^{\circ} \mathrm{S}\right)$ in the vicinity of the Tropical Front (SST: $\left.25^{\circ} \mathrm{C}\right)$ were characterized by warm $\left(>20^{\circ} \mathrm{C}\right)$ subsurface waters and a shoaling thermocline $(25 \mathrm{~m}$ deep) (Fig. 3A). The 200-m depth temperature $\left(12-16^{\circ} \mathrm{C}\right.$ ) between $35^{\circ} \mathrm{S}$ and $36^{\circ} \mathrm{S}$ confirmed we were in the Agulhas frontal region (Fig. 3B). Farther south $\left(38-39^{\circ} \mathrm{S}\right)$, the cooler sub-surface temperatures $\left(8-12^{\circ} \mathrm{C}\right)$ revealed we had reached the STC (Fig. 3C). Between $42^{\circ} \mathrm{S}$ and $43^{\circ} \mathrm{S}$, we encountered the cool subsurface temperatures $\left(4-8{ }^{\circ} \mathrm{C}\right)$ and deep thermocline $(50-75 \mathrm{~m})$ characteristic of the Sub-Antarctic Front 
(Fig. 3D). The two southern-most profiles $\left(47-48^{\circ} \mathrm{S}\right)$, confirmed we had not reached the cool $\left(<2^{\circ} \mathrm{C}\right)$ waters of the Polar Front (Fig. 3E).

In addition to these large-scale water mass characteristics, we documented smaller-scale gradients in water properties. The shelf-slope waters around the sub-Antarctic islands we visited (Crozet, Kerguelen, Amsterdam) were characterized by elevated CHL (Fig. 2F) and strong ( $>10 \%$ ) SST gradients (Fig. $2 \mathrm{H}$ ). We also sailed through waters of high pigment concentrations $\left(>0.3 \mu \mathrm{g} \mathrm{Chl} \mathrm{m}^{-3}\right)$ between Amsterdam Island and Western Australia (Fig. 2F), associated with a region of strong surface divergence (Hyrenbach et al., 2006).

\subsection{Seabird observations}

We surveyed $1541 \mathrm{~km}^{2}$ along a $5155 \mathrm{~km}$ cruise track over 16 days (Table 1). We sighted 15,606 seabirds belonging to 51 species, and identified $45.2 \%$ to species level. Prions composed $>89 \%$ of these unidentified individuals. The majority of the birds $(93.2 \%)$ we recorded were tubenoses (Procellariiformes), followed by penguins (Sphenisciformes) and Charadriiformes (gulls, terns, jaegers), each accounting for $\sim 3.2 \%$ of all individuals. Pelecaniformes (shags, tropicbirds) contributed $<1 \%$ of all birds (Appendix A).

\subsection{Oceanic habitats}

The habitat variables considered in this analysis were correlated: 20 of the 21 pair-wise comparisons yielded significant results at the coarse scale $(10 \mathrm{~s} \mathrm{~km})$ (Table 2A), while 9 of the 21 meso-scale $(100 \mathrm{~s} \mathrm{~km})$ correlations were significant (Table 2B). These cross-correlations revealed that shallower and cooler waters were characterized by elevated CHL.

\subsection{Seabird abundance}

Seabird abundance, when all taxa were combined, varied substantially across the study area, with the number of birds sighted within a given 9-km survey bin ranging from 0 to 1392 (density up to 515 birds $\mathrm{km}^{-2}$ ) (Fig. 4). We documented the highest densities (100-1000 birds km ${ }^{-2}$ ) close to the subAntarctic Islands of Crozet and Kerguelen, and off Western Australia. Intermediate densities (10-100 birds $\mathrm{km}^{-2}$ ) occurred in subtropical waters close to La Réunion, Western Australia, and Amsterdam Island.

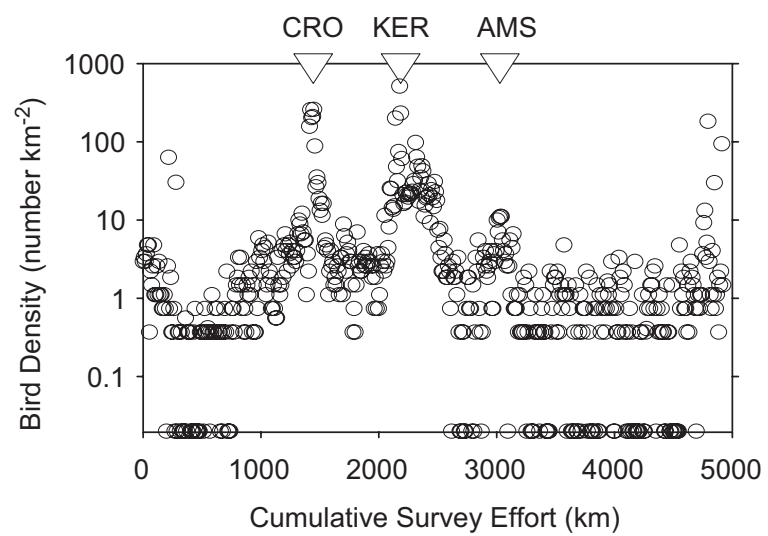

Fig. 4. Seabird density (number $\mathrm{km}^{-2}$ ) for 548 9-km survey bins along the survey track. The inverted triangles indicate the location of the islands of Crozet (CRO), Kerguelen (KER), and Amsterdam (AMS).

The autocorrelation analysis revealed positive Moran's $I$ values along the daily survey transects (mean $=0.37 \pm 0.26$ S.D., $n=16$ ). However, because these values were not indicative of strong autocorrelation patterns $(I>0.5)$, we used all the 548 survey bins for subsequent statistical analyses (van Franeker et al., 2002; Yen et al., 2004). The step-wise GLM results revealed that four of the nine environmental variables considered were significant, irrespective of whether we used the forwards or backwards selection procedure (Table 3). Seabird density was positively related to depth gradients, and negatively related to latitude, SST, and depth. The best-fit GLM model, including these four variables, was highly significant (ANOVA, $F$-ratio $=125.270$; $\mathrm{df}=4,543 ; p<0.001)$ and explained $47.6 \%$ of the variance in the log-transformed bird density data. The model residuals were normally distributed (Kolmogorov-Smirnov test, max_diff $=0.049, p=$ $0.148, n=548$ bins).

We used GAM models to visualize the response of seabird density to each of the significant variables identified by the GLM (Table 3). However, because shallower waters were characterized by steeper bathymetric gradients $(p<0.001)$ at both the coarse and the meso scale (Table 2A and B), we considered only SST and depth in the GAM analysis. Higher seabird densities occurred in cool ( $\mathrm{SST}<10^{\circ} \mathrm{C}$ ) subAntarctic waters, with intermediate densities in the frontal region between the Southern Subtropical Convergence $\left(\mathrm{SST}=13^{\circ} \mathrm{C}\right.$ ) and the Sub-Antarctic Front $\left(\mathrm{SST}=10^{\circ} \mathrm{C}\right)$. Seabird densities declined north of the Southern Subtropical Convergence, in spite of a slight increase along the Northern 
Table 3

Result of the step-wise GLM analysis of seabird density (individuals $\mathrm{km}^{-2}$ )

\begin{tabular}{|c|c|c|c|c|}
\hline Variable & Coefficient & $t$ statistic & $p$ value & Effect \\
\hline Latitude & -0.103 & -6.699 & $<0.001$ & Higher bird densities in southern latitudes \\
\hline SST & -0.147 & -8.866 & $<0.001$ & Higher bird densities in cooler waters \\
\hline Depth & -0.002 & -3.705 & $<0.001$ & Higher bird densities in shallower waters \\
\hline Depth gradient & +0.008 & +4.266 & $<0.001$ & Higher bird densities in steeper regions \\
\hline
\end{tabular}

Dependent variable: $\log ($ bird density +0.1$)$.

Independent variables: latitude, longitude, wind speed, SST, SST gradient, CHL, CHL gradient, depth, depth gradient.

For each significant variable, the positive $(+)$ or negative $(-)$ resulting coefficient, the $t$-statistic, and the associated $p$-value are shown.
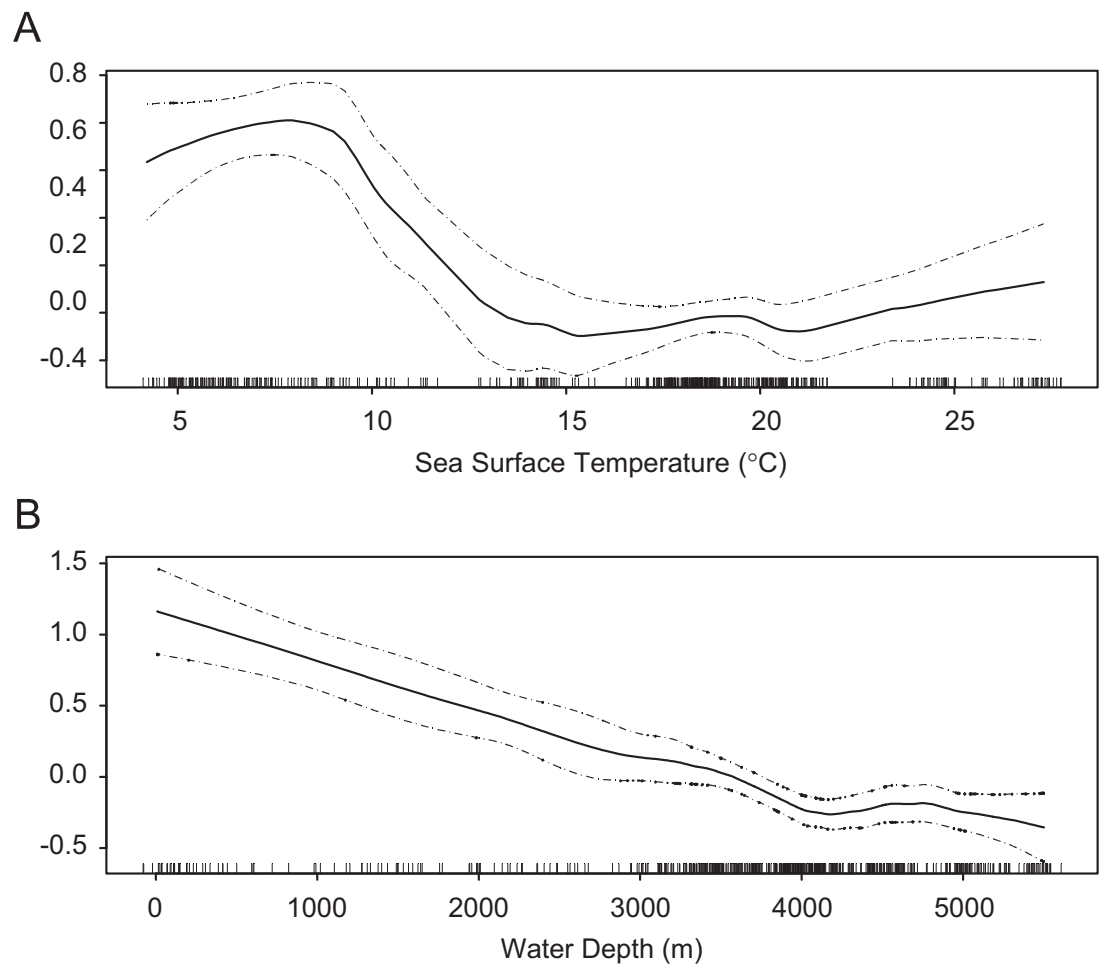

Fig. 5. Generalized additive model (GAM) results, illustrating the relationship between seabird density (numberkm ${ }^{-2}$ ) and two environmental variables: (A) latitude and (B) water depth. These graphs show the same sample size of 548 9-km survey bins. To better illustrate the shape of each relationship, the scaling of the $y$-axis differs for each variable.

Subtropical Convergence $\left(\mathrm{SST}=17^{\circ} \mathrm{C}\right)($ Fig. 5A). We also detected a seabird response to water depth (Fig. 5B). Seabird densities declined as water depth increased, with the lowest densities over the deep waters beyond shelf-slope regions (depth $>3000 \mathrm{~m}$ ) (Fig. 5B).

\subsection{Seabird community structure}

Because our observations were interrupted by nighttime periods, the community analysis considered 16 disjunct daily transects (Fig. 1). The NMDS procedure selected three habitat axes, which together accounted for $73.4 \%$ of the variance observed in the marine bird community. The first axis $\left(r^{2}=0.15\right)$ described latitudinal gradients associated with a concurrent SST decrease and CHL increase. The second axis $\left(r^{2}=0.41\right)$ illustrated concurrent latitudinal/longitudinal changes in wind speed, depth, CHL, and SST, as well as gradients in ocean depth and SST. The third axis $\left(r^{2}=0.17\right)$ captured the influence of onshore-offshore gradients in CHL, irrespective of latitude and longitude (Table 4). Because the second and third axes explained a larger 
proportion of the observed variability, we plotted the survey transects and species distributions (for the 29 most numerous taxa with $>25$ individuals), on these two dimensions.

Three clusters of transects were apparent: subtropical nearshore (3 transects: \#1, 2, 16), subtropical offshore (5 transects: \# 3 and 12-15), and the confluence between subtropical and subAntarctic waters (8 transects: \# 4-11) (Fig. 6A). The nearshore subtropical transects were characterized by warm SST $\left(>20^{\circ} \mathrm{C}\right)$ and low $\mathrm{CHL}$ $\left(<0.1 \mathrm{mg} \mathrm{m}^{-3}\right)$. In spite of surveying deep water off the shelf-slope (depth $>2000 \mathrm{~m}$ ), transects 1 and 16 supported large bird numbers $\left(>1\right.$ birds km ${ }^{-2}$ ), dominated by locally-breeding species: dark terns (DKTE) S. fuscata/anaethetus, wedge-tailed shearwaters (WTSH) Puffinus pacificus, Barau's petrel (BAPT) Pterodroma baraui. The third transect in this cluster (\#2), was characterized by similar environmental conditions but supported the lowest bird densities observed during the entire survey $\left(0.24\right.$ birds $\left.\mathrm{km}^{-2}\right)$, and an avifauna dominated by the Bulwer's petrel Bulweria bulwerii (Table 5). The six offshore subtropical transects were aligned north of the Subtropical Convergence (SST: $17^{\circ} \mathrm{C}$ ), along a narrow latitude band $\left(30.25-37.5^{\circ} \mathrm{S}\right)$ (Fig. 1). These transects supported lower seabird densities $\left(<1\right.$ birds $\mathrm{km}^{-2}$ ) dominated by great-winged petrels (GWPT) Pterodroma macroptera, which accounted for $60-90 \%$ of all birds sighted (Table 5). The third cluster was the most heterogeneous, both in terms of the environmental conditions and the composition of the avifauna. As we sailed from the waters north of the Agulhas Front (transects \#4, 11), across the STC (transect \#10), through the Sub-Antarctic Front (transect \#5), and into sub-Antarctic waters (transects \#6-9), we documented decreasing SST

Table 4

Pearson's correlation coefficients between the nine environmental variables and the three non-dimensional multidimensional scaling (NDMS) axes used to characterize seabird oceanographic habitats

\begin{tabular}{lccc}
\hline Environmental variable & Axis 1 & Axis 2 & Axis 3 \\
\hline Median longitude (LON) & +0.195 & -0.627 & -0.240 \\
Median latitude (LAT) & -0.770 & -0.707 & -0.455 \\
Median wind speed (WSP) & +0.343 & +0.673 & +0.108 \\
Median depth (DPT) & -0.430 & -0.518 & -0.518 \\
Median sea-surface temperature (SST) & -0.703 & -0.739 & -0.412 \\
Median chlorophyll-a concentration (CHL) & +0.622 & +0.595 & +0.584 \\
C.V. depth (DCV) & +0.361 & +0.619 & +0.305 \\
C.V. sea-surface temperature (TCV) & +0.333 & +0.595 & +0.368 \\
C.V. chlorophyll-a concentration (CCV) & +0.350 & +0.374 & +0.417 \\
\hline
\end{tabular}
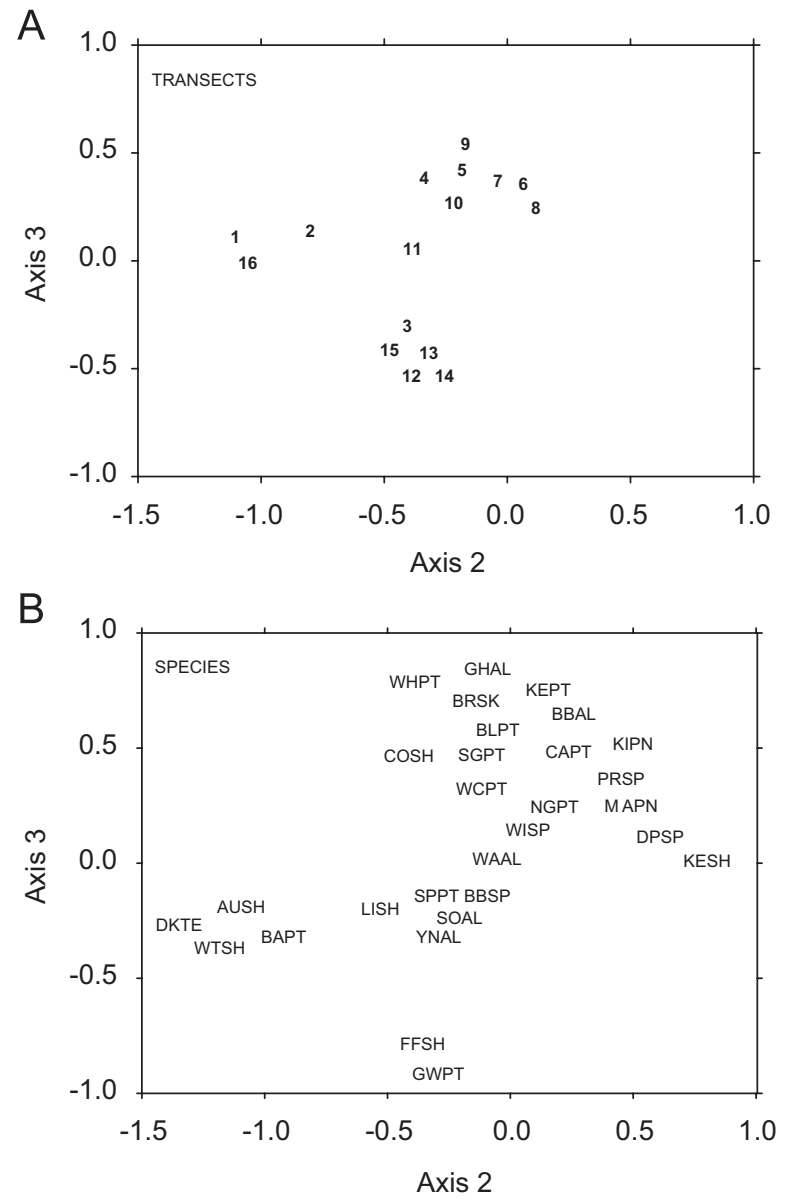

Fig. 6. Results of NMDS analysis of seabird community structure along 16 daily meso-scale transects (A). For the sake of clarity, only the 29 most numerous taxa are shown in this diagram (B) (see Appendix A for taxonomic codes). These plots highlight the two axes that accounted for most of the observed variability.

and increasing CHL. Concurrently, we transitioned from a community dominated by surface-feeding albatross (Indian Ocean yellow-nosed Thallasarche carteri) and petrels (soft-plumaged Pterodroma mollis, white-chinned Procellaria aequinoctialis), to a prion-dominated avifauna (Table 5).

\subsection{Biogeographic domains}

We surveyed three biogeographic domains with different physical and biological characteristics. The SST warmed (Fig. 2E), the thermocline deepened, (Fig. 3), the CHL standing stock (an index of phytoplankton abundance) increased (Fig. 2F), and the density of seabirds (Fig. 5A) increased as we 
Table 5

Physical and biological conditions observed along 16 meso-scale transects (Fig. 1)

\begin{tabular}{|c|c|c|c|c|c|c|c|}
\hline $\begin{array}{l}\text { Transect } \\
\text { number }\end{array}$ & $\begin{array}{l}\text { Survey } \\
\text { effort } \\
\left(\mathrm{km}^{2}\right)\end{array}$ & $\begin{array}{l}\text { Bird density } \\
\text { mean (S.D.) } \\
\left(\# \mathrm{~km}^{-2}\right)\end{array}$ & $\begin{array}{l}\text { Dominant taxa } \\
\text { (\% birds sighted })\end{array}$ & $\begin{array}{l}\text { Wind speed } \\
\text { median (C.V.) } \\
\left(\mathrm{km} \mathrm{h}^{-1}\right)\end{array}$ & $\begin{array}{l}\text { SST } \\
\text { median (C.V.) } \\
\left({ }^{\circ} \mathrm{C}\right)\end{array}$ & $\begin{array}{l}\mathrm{CHL} \\
\text { median (C.V.) } \\
\left(\mathrm{mg} \mathrm{m}^{-3}\right)\end{array}$ & $\begin{array}{l}\text { Depth } \\
\text { median (C.V.) } \\
(\mathrm{m})\end{array}$ \\
\hline 1 & 97.20 & $4.15(11.30)$ & DKTE (44.30) & $19(10.51)$ & $27.15(1.81)$ & $0.06(11.29)$ & $4086.5(7.47)$ \\
\hline 2 & 67.18 & $0.24(0.24)$ & BUPT (37.50) & $15(45.38)$ & $24.45(1.58)$ & $0.065(12.50)$ & $4982.5(3.07)$ \\
\hline 3 & 72.90 & $0.52(0.50)$ & GWPT (58.90) & $12(27.07)$ & $21(2.38)$ & $0.07(23.34)$ & $4252.0(9.60)$ \\
\hline 4 & 94.50 & $2.01(1.40)$ & SPPT (23.90) & $21(3.55)$ & $18.15(3.01)$ & $0.20(23.41)$ & $3891.0(12.61)$ \\
\hline 5 & 87.30 & $4.14(2.76)$ & PRSP (34.20) & $10(40.75)$ & $9(10.65)$ & $0.29(18.64)$ & $3436.0(3.08)$ \\
\hline 6 & 78.30 & $47.91(82.44)$ & PRSP (73.70) & $41(9.32)$ & $6(4.67)$ & $0.21(21.47)$ & $3544.0(46.68)$ \\
\hline 7 & 111.60 & $2.81(1.72)$ & PRSP (43.30) & $43(4.58)$ & $5.47(10.40)$ & $0.22(8.61)$ & $3569.5(23.93)$ \\
\hline 8 & 48.60 & $72.82(128.42)$ & PRSP (74.60) & $38.5(13.88)$ & $4.54(7.12)$ & $0.22(47.75)$ & $19.0(143.77)$ \\
\hline 9 & 113.22 & $21.96(18.27)$ & WCPT (29.30) & $28(8.60)$ & 7.27 (20.98) & $0.195(77.44)$ & $2881.0(67.13)$ \\
\hline 10 & 105.30 & $1.46(1.36)$ & SPPT (21.80) & $14(40.53)$ & $14.25(4.72)$ & $0.26(19.70)$ & $3307.0(12.94)$ \\
\hline 11 & 62.10 & $4.72(3.34)$ & YNAL (69.00) & $10(29.49)$ & $17.7(1.75)$ & $0.33(28.14)$ & $1412.0(39.19)$ \\
\hline 12 & 116.10 & $0.70(0.67)$ & GWPT (89.00) & $16(12.76)$ & $18.15(2.08)$ & 0.18 (11.87) & $3753.0(3.82)$ \\
\hline 13 & 113.40 & $0.75(0.88)$ & GWPT (88.37) & $16(12.67)$ & $18.45(0.99)$ & 0.13 (10.69) & $3998.5(1.56)$ \\
\hline 14 & 110.12 & $0.73(0.88)$ & GWPT (90.00) & $12(7.36)$ & $18.9(1.74)$ & $0.27(30.32)$ & $4500.0(1.77)$ \\
\hline 15 & 105.30 & $0.84(0.96)$ & GWPT (79.78) & $11(22.17)$ & $19.65(2.88)$ & 0.06 (16.69) & $5457.0(2.12)$ \\
\hline 16 & 89.10 & $11.42(35.08)$ & WTSH (80.75) & $14(36.64)$ & $20.55(2.83)$ & $0.12(12.80)$ & $5003.0(2.53)$ \\
\hline
\end{tabular}

For each transect, the four most numerically abundant taxa are listed. Dominance is expressed as the relative proportion of all the birds sighted during each transect. See Appendix A for taxonomic codes.

sailed from subtropical to sub-Antarctic waters (Table 1).

The waters north and south of the STC supported distinct seabird communities, with an order of magnitude higher mean densities in the sub-Antarctic domain (23.8 birds $\mathrm{km}^{-2}$ ) than in the subtropical domain (2.4 birds $\mathrm{km}^{-2}$ ) (Table 1). Prions (PRSP) were the dominant sub-Antarctic seabirds, contributing $57 \%$ of all the birds sighted in this domain. Together with three other species (whitechinned petrel WCPT, Wilson's storm-petrel WISP, black-browed albatross BBAL), they accounted for $79 \%$ of all the birds in the sub-Antarctic domain (Table 5). The WTSH was the most numerous species in the subtropical region, contributing $46 \%$ of all the birds sighted in this domain. Together with GWPT, DKTE, and BAPT, they accounted for $84 \%$ of all the birds in the subtropical domain (Table 5).

When we contrasted the composition of the avifauna within the subtropical and sub-Antarctic domains, we found no significant relationship between the ranks of species abundance (Spearman correlation, $r_{\mathrm{s}}=-0.06, p<0.50, n=50$ taxa sighted in at least one domain). This faunal difference was also evident in the relative contribution of different feeding guilds. The number of diving birds and species was proportionally more numerous in the
sub-Antarctic domain. Conversely, plunging birds and species were proportionally more numerous in the subtropical domain (Table 1).

The southern subtropical convergence region (SSTC) between the ISSG and the SAWR was characterized by seabird densities comparable to those found in subtropical waters (Table 1). Nevertheless, the SSTC avifauna was unique (Table 5). Four species (Indian Ocean yellow-nosed albatross YNAL, soft-plumaged petrel SPPT, Cory's shearwater $\mathrm{COSH}$, white-chinned petrel WCPT) accounted for $58 \%$ of all birds in the SSTC. The composition of the SSTC avifauna was not significantly correlated with that in the ISSG (Spearman correlation, $r_{\mathrm{s}}=-0.004, p<0.50, n=40$ taxa) or in the SAWR (Spearman correlation, $r_{\mathrm{s}}=-0.049, p<0.50, n=43$ taxa). The transitional nature of the SSTC avifauna is underscored by the relative contribution of different feeding guilds. Both divers and plungers occurred in this domain, accounting for intermediate numbers of individuals and species (Table 1). Yet, when we contrasted the relative abundance of the different foraging guilds (divers, plungers, surface feeders) across these three biogeographic domains using $G$ tests, we found significant differences in the proportion of individuals $(G=32.157, p<0.001, \mathrm{df}=4)$ and species $(G=36.396, p<0.001, \mathrm{df}=4)$. 


\section{Discussion}

Our study suggests that the avifauna of the southern Indian Ocean is structured by large-scale $(\sim 1000 \mathrm{skm})$ gradients in physical and biological properties. We surveyed a 3000-km north-south transect spanning subtropical to sub-Antarctic waters, and documented a shift in seabird communities along a large-scale $\left(22-50^{\circ} \mathrm{S}\right)$ latitudinal gradient in surface (SST and CHL) and sub-surface (MLD) water properties. Cooler sub-Antarctic waters of higher ocean productivity and phytoplankton standing stocks supported an order of magnitude higher seabird densities, than lower productivity subtropical waters. This result is consistent with past at-sea surveys, which have documented higher bird densities in sub-Antarctic waters than in less productive subtropical and tropical regions (Griffiths et al., 1982; Stahl et al., 1985). In addition to supporting different seabird densities, the species assemblages in sub-Antarctic and subtropical waters were markedly distinct. The sub-Antarctic domain contained a higher proportion of individuals and species that dive to forage; while the subtropical domain was characterized by a disproportionate abundance of seabirds that plunge in pursuit of prey.

Frontal systems structure seabird communities by delimiting species distributions and by enhancing local aggregations. Adjacent water masses on both continental shelves (e.g., Schneider et al., 1986) and oceanic systems (e.g., Spear et al., 2001) often support distinct seabird assemblages and foraging guilds, suggesting that frontal boundaries delineate species distributions and segregate functional ecosystems. Fronts are also sites of seabird aggregation, due to enhanced prey availability and concentration. This enhancement effect can yield elevated localized densities, 10-100 times larger than the background levels for a given water mass (Hunt et al., 1996; Begg and Reid, 1997; Hoefer, 2000). There is ample evidence that seabirds aggregate at narrow frontal systems (Rossby radius $<10 \mathrm{~km}$ ) within productive sub-polar and temperate continental shelves (e.g., for a review see Schneider, 1982; Hunt and Schneider, 1987; Schneider et al., 1987; Hunt et al., 1999). However, very little research has been devoted to characterizing seabird aggregation and community structure across oceanic fronts, especially in unproductive subtropical waters with low bird densities (but see Spear et al., 2001).
We documented a change in seabird community structure across the SSTC, suggesting that this frontal system separates the subtropical and the sub-Antarctic avifauna. While most taxa were restricted to waters south (e.g., penguins) and north (e.g., tropicbirds) of this frontal system, some cosmopolitan species (e.g., white-chinned petrel) ranged across all three domains. However, when we considered the entire avifauna, the ISSG and the SAWR supported statistically distinct species assemblages.

The SSTC was characterized by a unique avifauna, with the presence of non-breeding (e.g., Cory's shearwaters from the Atlantic Ocean) and locally-breeding (e.g., Indian Ocean yellow-nosed albatross from Amsterdam Island) species. However, we did not detect a local "enhancement" effect, with higher bird densities along the SSTC, suggesting that this broad $(\sim 100 \mathrm{~km})$ frontal system is not a site of seabird aggregation.

We also documented seabird responses to smaller-scale onshore-offshore gradients, with higher densities within the shelf-slope regions around islands than in deeper oceanic waters. These shallow peri-insular regions were also characterized by elevated $\mathrm{CHL}$ and by strong water property gradients. These results underscore the notion that seabirds aggregate and forage on the shelf-slope waters surrounding Crozet, Kerguelen, and Amsterdam (Catard et al., 2000; Cherel et al., 2000; Pinaud et al., 2005), and highlight the importance of the location of breeding sites as determinants of marine bird community structure at-sea during the breeding season (Stahl et al., 1985; Weimerskirch et al., 1988; Jaquemet et al., 2004).

This colony effect was particularly evident in the vicinity of the islands we visited along the cruise track. For instance, the avifauna found along transect \#11 (between St. Paul Island and Amsterdam Island), was different from the subtropical avifauna to the east and west (transects \#3, 12-15) due to the prevalence of the locally-breeding Indian Ocean yellow-nosed albatross, which accounted for $\sim 70 \%$ of all the birds sighted. Even though these albatross forage up to $2000 \mathrm{~km}$ from their colony in January, when they occupy subtropical and Agulhas Front waters, they also spend about $60 \%$ of their time at-sea over the peri-insular slope (1000-3000 m depth) around Amsterdam Island (Pinaud et al., 2005). The influence of seabird colonies was also evident south of the Sub-Antarctic Front. The two transects in the vicinity of the archipelagos of 
Crozet (\#6) and Kerguelen (\#8) were dominated by locally-breeding prions, which accounted for approximately three-quarters of all the birds sighted. Similarly, the transect along the shallow plateau north-east of Kerguelen (\#9) was characterized by high numbers of white-chinned petrels, a locallybreeding species known to forage along the shelfbreak (Catard et al., 2000).

We also encountered high densities ( $>1$ bird$\mathrm{s} \mathrm{km}^{-2}$ ) of locally-breeding subtropical species (DKTE, WTSH) along deep-water $(>2000 \mathrm{~m})$ transects close to shore (\#1 and 16). These species breed on islands off Western Australia during the austral summer and occur over warm water (SST $>20^{\circ} \mathrm{C}$ ) off the continental shelf (depth $>200 \mathrm{~m}$ ), where they forage on oceanic prey (squid, lanterfish) (Surman and Wooller, 2000, 2003). Sooty and bridled terns and WTSHs are also frequent off La Réunion, especially during the summer breeding season (Jaquemet et al., 2004).

This study provides a multi-disciplinary perspective of the oceanographic processes influencing seabird communities across the southern Indian Ocean. Our results highlight the importance of large-scale latitudinal ecotones and onshore-offshore gradients, as determinants of marine bird density and community structure. To place our observations in a broader context, we constructed averages of the physical and biological conditions for the study area. These monthly climatologies reinforce the results of our cruise, suggesting that the conditions we observed during January 2003 are indicative of the long-term average conditions in the study area.

\section{Acknowledgments}

We are grateful to the officers and crew of the R.V. Marion Dufresne, to the French Polar Institute Paul-Emile Victor (IPEV, program no. 109) for facilitating our participation in this cruise, and to LOCEAN-IPSL for supporting the Ocean Indien Service d'Observation (OISO) program. The US National Science Foundation Office of Polar Programs supported GLH and KDH (Grant OPP0234570) and RRV (Grant OPP-9983751). The Pacific Fisheries Environmental Laboratory and the Coriolis program provided the hydrographic data. The Pathfinder, SeaWiFS, and MODIS programs provided the remote sensing data. Lisa Ballance, Michael Bacon and an anonymous reviewer greatly improved this paper.

\section{Appendix A}

Seabird observations compiled during this study (Table A.1).

Table A.1

Summary of seabird observations across the southern Indian Ocean (January 2003), showing only the "common" species ( $>25$ individuals) and the most numerous species during 16 daily transects (Table 5). The following breeding locations are considered: Prince Edward and Marion Islands (PM), Crozet Islands (CI), Amsterdam and St. Paul Island (AS), Kerguelen Islands (KI), Heard and McDonald Islands (HM), La Réunion Island (RE), Tropical Indian Ocean (TI), and Western Australia (WA). Four feeding guilds are considered: surface-feeders (SS), divers (DI), plungers (PL), and kleptoparasites (KL)

\begin{tabular}{|c|c|c|c|c|c|}
\hline Common name & Scientific name & Breeding locations & Feed. guild & Total birds & Prop. $(\%)$ \\
\hline Audubon Shearwater (AUSH) & Puffinus lherminieri & RE, TI & DI & 46 & 0.29 \\
\hline Black-browed Albatross (BBAL) & Thallasarche melanophris & CI, KI, HM & SS & 442 & 2.83 \\
\hline Black-bellied Storm-petrel (BBSP) & Fregetta tropica & PM, CI, KI & SS & 252 & 1.61 \\
\hline Blue Petrel (BLPT) & Halobaena caerulea & PM, CI, KI & SS & 288 & 1.85 \\
\hline Barau's Petrel (BAPT) & Pterodroma baraui & $\mathrm{RE}$ & SS & 87 & 0.56 \\
\hline Bulwer's Petrel (BUPT) & Bulweria bulwerii & Non-breeding & SS & 14 & 0.09 \\
\hline Cape Petrel (CAPT) & Daption capense & $\mathrm{CI}, \mathrm{KI}, \mathrm{HM}$ & SS & 190 & 1.22 \\
\hline Cory's Shearwater (COSH) & Calonectris diomedea & Non-breeding & SS & 42 & 0.27 \\
\hline Flesh-footed Shearwater (FFSH) & Puffinus carneipes & AS & SS & 31 & 0.20 \\
\hline Grey-headed Albatross (GHAL) & Thallasarche chrysostoma & PM, KI & SS & 58 & 0.37 \\
\hline Great-winged Petrel (GWPT) & Pterodroma macroptera & PM, CI, AS, KI, HM & SS & 368 & 2.36 \\
\hline Kerguelen Petrel (KEPT) & Pterodroma brevirostris & $\mathrm{PM}, \mathrm{CI}, \mathrm{KI}$ & SS & 57 & 0.37 \\
\hline Little Shearwater (LISH) & Puffinus assimilis & AS & DI & 63 & 0.40 \\
\hline Northern Giant Petrel (NGPT) & Macronectes halli & PM, CI, KI, HM & SS & 113 & 0.72 \\
\hline Southern Giant Petrel (SGPT) & Macronectes giganteus & PM, CI, KI, HM & SS & 89 & 0.57 \\
\hline Sooty Albatross (SOAL) & Phoebetria fusca & PM, CI, AS, KI & SS & 49 & 0.31 \\
\hline
\end{tabular}


Table A.1 (continued)

\begin{tabular}{|c|c|c|c|c|c|}
\hline Common name & Scientific name & Breeding locations & Feed. guild & Total birds & Prop. $(\%)$ \\
\hline Soft-plumaged Petrel (SPPT) & Pterodroma mollis & PM, CI, AS, KI & SS & 300 & 1.92 \\
\hline Diving Petrels (DPSP) & Pelecanoides spp. & PM, CI, KI, HM & DI & 500 & 3.20 \\
\hline Prions (PRSP) & Pachyptila spp. & $\mathrm{PM}, \mathrm{CI}, \mathrm{AS}, \mathrm{KI}, \mathrm{HM}$ & SS & 7743 & 49.68 \\
\hline Wandering albatross (WAAL) & Diomedea exulans & PM, CI, KI, HM & SS & 132 & 0.85 \\
\hline White-chinned Petrel (WCPT) & Procellaria aequinoctialis & PM, CI, KI & SS & 1615 & 10.35 \\
\hline White-headed Petrel (WHPT) & Pterodroma lessonii & PM, CI, KI, HM & SS & 44 & 0.28 \\
\hline Wilson’s Storm-petrel (WISP) & Oceanites oceanicus & $\mathrm{KI}, \mathrm{HM}$ & SS & 703 & 4.50 \\
\hline Wedge-tailed Shearwater (WTSH) & Puffinus pacificus & RE, TI, WA & SS & 899 & 5.76 \\
\hline Yellow-nosed Albatross (YNAL) & Thallasarche carteri & $\mathrm{PM}, \mathrm{CI}, \mathrm{AS}, \mathrm{KI}$ & SS & 245 & 1.57 \\
\hline Total Procellariiformes & & & & 14546 & 93.21 \\
\hline King Penguin (KIPN) & Aptenodytes patagonicus & PM, CI, KI, HM & DI & 29 & 0.19 \\
\hline Macaroni Penguin (MAPN) & Eudyptes chrysolophus & PM, CI, KI, HM & DI & 403 & 2.58 \\
\hline Total Sphenisciformes & & & & 494 & 3.17 \\
\hline Brown Skua (BRSK) & Catharacta skua lonnbergi & $\mathrm{PM}, \mathrm{CI}, \mathrm{AS}, \mathrm{KI}, \mathrm{HM}$ & KL & 43 & 0.28 \\
\hline Dark Tern (DKTE) & Sterna fuscata/anaethetus & TI, WA & PL & 417 & 2.67 \\
\hline Total Charadriiformes & & & & 492 & 3.15 \\
\hline Kerguelen Shag (KESH) & Phalacrocorax atriceps & CI, KI & DI & 70 & 0.45 \\
\hline Total Pelecaniformes & & & & 74 & 0.47 \\
\hline Grand total & & & & 15606 & 100 \\
\hline
\end{tabular}

\section{References}

Begg, G.S., Reid, J.B., 1997. Spatial variation in seabird density at a shallow sea tidal mixing front in the Irish Sea. ICES Journal of Marine Science 54, 552-565.

Boyer, T.P., Conkright, M.E., Levitus, S., Stephens, C., O’ Brien, T., Johnson, D., Gelfeld, R., 1998. NOAA Atlas NESDIS 21, World Ocean Database 1998. US Government Printing Office, Washington, DC.

Casey, K.S., 2002. Daytime vs nighttime AVHRR sea surface temperature data: a report regarding Wellington et al. (2001). Bulletin of Marine Science 70, 169-175.

Catard, A., Weimerskirch, H., Cherel, Y., 2000. Exploitation of distant Antarctic waters and close shelf-break waters by white-chinned petrels rearing chicks. Marine Ecology-Progress Series 194, 249-261.

Cherel, Y., Weimerskirch, H., Trouve, C., 2000. Food and feeding ecology of the neritic-slope forager black-browed albatross and its relationships with commercial fisheries in Kerguelen waters. Marine Ecology-Progress Series 207, 183-199.

Clarke, E.D., Spear, L.B., McCracken, M.L., Marques, F.F.C., Borchers, D.L., Buckland, S.T., Ainley, D.G., 2003. Validating the use of generalized additive models and at-sea surveys to estimate size and temporal trends of seabird populations. Journal of Applied Ecology 40, 278-292.

Cresswell, G.R., Peterson, J.L., 1993. The Leeuwin Current south of Western Australia. Australian Journal of Marine and Freshwater Research 44, 285-303.

Dixon, T.J., 1977. The distance at which sitting birds can be seen at sea. Ibis $119,372-375$.

Duffy, D.C., 1983. The effect of wave height on bird counts at sea. Cormorant 11, 21-24.
Esaias, W.E., 1996. Algorithm theoretical basis document for MODIS product MOD 27 Ocean Primary Productivity (ATBD MOD-24). 〈http://eospso.gsfc.nasa.gov/atbd/modistables.html >.

Fiala, M., Delille, B., Dubreuil, C., Kopczynska, E., Leblanc, K., Morvan, J., Queguiner, B., Blain, S., Cailliau, C., Conan, P., Corvaisier, R., Denis, M., Frankignoulle, M., Oriol, L., Roy, S., 2003. Mesoscale surface distribution of biogeochemical characteristics in the Crozet Basin frontal zones (South Indian Ocean). Marine Ecology-Progress Series 249, 1-14.

Furuya, K., Hasumoto, H., Nakai, T., Nemoto, T., 1986. Phytoplankton in the subtropical convergence during the austral summer - community structure and growth-activity. Deep-Sea Research 33, 621-630.

Franks, P.J.S., 1992. Sink or swim - accumulation of biomass at fronts. Marine Ecology-Progress Series 82, 1-12.

Griffiths, A.M., Siegfried, W.R., Abrams, R.W., 1982. Ecological structure of a pelagic seabird community in the Southern Ocean. Polar Biology 1, 39-46.

Guisan, A., Edwards, T.C., Hastie, T., 2002. Generalized linear and generalized additive models in studies of species distributions: setting the scene. Ecological Modeling 157, 89-100.

Harper, P.C., Croxall, J.P., Cooper, J., 1985. A guide to foraging methods used by marine birds in Antarctic and Subantarctic seas. Biomass Handbook 24, 1-22.

Haury, L.R., Mc Gowan, J.A., Wiebe, P.H., 1978. Patterns and processes in the time-space scales of plankton distributions. In: Steele, J.H. (Ed.), Spatial Patterns in Plankton Communities. Plenum Press, New York, pp. 277-327.

Hoefer, C.J., 2000. Marine bird attraction to thermal fronts in the California Current System. Condor 102, 423-427.

Hoge, F.E., Lyon, P.E., Swift, R.N., Yungel, J.K., Abbott, M.R., Letelier, R.M., Esaias, W.E., 2003. Validation of Terra-MODIS 
phytoplankton chlorophyll fluorescence line height. I. Initial airborne lidar results. Applied Optics 42, 2767-2771.

Hooker, S.B., McClain, C.R., 2000. The calibration and validation of SeaWiFS data. Progress in Oceanography 45, 427-465.

Hui, C.A., 1985. Undersea topography and the comparative distributions of two pelagic cetaceans. Fishery Bulletin 83, 472-475.

Hunt Jr., G.L., Schneider, D.C., 1987. Scale dependent processes in the physical and biological environment of seabirds. In: Croxall, J.P. (Ed.), The Feeding Ecology of Seabirds and Their Role in Marine Ecosystems. Cambridge University Press, Cambridge, pp. 7-41.

Hunt Jr., G.L., Coyle, K.O., Hoffman, S., Decker, M.B., Flint, E.N., 1996. Foraging ecology of short-tailed shearwaters near the Pribilof Islands, Bering Sea. Marine Ecology-Progress Series 141, 1-11.

Hunt Jr., G.L., Mehlum, F., Russell, R.W., Irons, D., Decker, M.B., Becker, P.H., 1999. Physical processes, prey abundance, and the foraging ecology of seabirds. Proceedings International Ornithological Congress 22, 2040-2056.

Hyrenbach, K.D., Veit, R.R., Weimerskirch, H., Hunt Jr., G.L., 2006. Seabird associations with mesoscale eddies: the subtropical Indian Ocean. Marine Ecology-Progress Series 324, 271-279.

Inchausti, P., Guinet, C., Koudil, M., Durbec, J.P., Barbraud, C., Weimerskirch, H., Cherel, Y., Jouventin, P., 2003. Interannual variability in the breeding performance of seabirds in relation to oceanographic anomalies that affect the Crozet and the Kerguelen sectors of the Southern Ocean. Journal of Avian Biology 34 (2), 170-176.

Jaquemet, S., Le Corre, M., Weimerskirch, H., 2004. Seabird community structure in a coastal tropical environment: importance of natural factors and fish aggregating devices (FADs). Marine Ecology-Progress Series 268, 281-292.

Kenkel, N.C., Orloci, L., 1986. Applying metric and nonmetric multidimensional scaling to ecological studies: some new results. Ecology 67, 919-923.

Kostianoy, A.G., Ginzburg, A.I., Frankignoulle, M., Delille, B., 2004. Fronts in the southern Indian Ocean as inferred from satellite temperature data. Journal of Marine Systems 45, 55-73.

Longhurst, A., 1998. Ecological Geography of the Sea. Academic Press, San Diego, CA.

Lutjeharms, J.R.E., 1985. Location of frontal systems between Africa and Antarctica: some preliminary results. Deep-Sea Research 32, 1499-1509.

Lutjeharms, J.R.E., Walters, N.M., Allanson, B., 1985. Oceanic frontal systems and biological enhancement. In: Siegfried, W.R., Condy, P.R., Laws, R.M. (Eds.), Antarctic Nutrient Cycles and Food Webs. Proceedings of the Fourth Symposium on Antarctic Biology. Springer, Berlin, pp. 11-21.

Manly, B.F.J., 1994. Multivariate Statistical Methods. A Primer, second ed. Chapman \& Hall, New York.

McCune, B., Mefford, M.J., 1999. PC-ORD: Multivariate Analysis of Ecological Data (version 4). MjM Software Design, Gleneden Beach, OR.

Metzl, N., Beauverger, C., Brunet, C., Goyet, C., Poisson, A., 1991. Surface water carbon dioxide in the southwest Indian Sector of the Southern Ocean: a highly variable $\mathrm{CO}_{2}$ source/ sink region in summer. Marine Chemistry 35, 85-95.
Monterey, G., Levitus, S., 1997. Seasonal Variability of Mixed Layer Depth for the World Ocean. NOAA Atlas, NESDIS 14, Washington, DC, (100pp.).

Moore, J.K., Abbott, M.R., Richman, J.G., 1999. Location and dynamics of the Antarctic Polar Front from satellite sea surface temperature data. Journal of Geophysical ResearchOceans 104 (C2), 3059-3073.

NGDC (National Geophysical Data Center), 1998. Data Announcement 88-MGG-02, Digital relief of the surface of the Earth. Boulder, National Geophysical Data Center. 〈www.ngdc.noaa.gov/mgg/global/seltopo.html〉.

Park, Y.H., Gambéroni, L., 1995. Large-scale circulation and its variability in the South Indian Ocean from TOPEX/POSEIDON altimetry. Journal of Geophysical Research - Oceans 100 (C12), 24911-24929.

Park, Y.H., Gambéroni, L., Charriaud, E., 1993. Frontal structures, water masses, and circulation in the Crozet Basin. Journal of Geophysical Research-Oceans 98 (C7), 12361-12385.

Park, Y.H., Pollard, R.T., Read, J.F., Leboucher, V., 2002. A quasi-synoptic view of the frontal circulation in the Crozet Basin during the Antares-4 cruise. Deep-Sea Research II 49, 1823-1842.

Pinaud, D., Cherel, Y., Weimerskirch, H., 2005. Effect of environmental variability on habitat selection, diet, provisioning behaviour and chick growth in Yellow-nosed Albatrosses. Marine Ecology-Progress Series 298, 295-304.

Pocklington, R., 1979. An oceanographic interpretation of seabird distributions in the Indian Ocean. Marine Biology $51,9-21$.

Polovina, J.J., Balazs, G.H., Howell, E.A., Parker, D.M., Seki, M.P., Dutton, P.H., 2004. Forage and migration habitat of Loggerhead (Caretta caretta) and Olive Ridley (Lepidochelys olivacea) Sea Turtles in the central North Pacific Ocean. Fisheries Oceanography 13, 36-51.

Reynolds, R.W., Smith, T.M., 1994. Improved global sea surface temperature analyses using optimum interpolation. Journal of Climate 7, 929-948.

Rio, M.H., Hernández, F., 2003. High-frequency response of wind-driven currents measured by drifting buoys and altimetry over the world ocean. Journal of Geophysical Research-Oceans 108 (C8), 3283.

Roemmich, D., Riser, S., Davis, R., Desaubies, Y., 2004. Autonomous profiling floats: workhorse for broad-scale ocean observations. Marine Technology Society Journal 38, 21-29.

Sawada, M., 1999. Rookcase: an excel 97/2000 visual basic add-in for exploring global and local spatial autocorrelation. Bulletin of the Ecological Society of America 80, 231-234.

Schneider, D.C., 1982. Fronts and seabird aggregations in the southeastern Bering Sea. Marine Ecology-Progress Series 10, 101-103.

Schneider, D.C., 1997. Habitat selection by marine birds in relation to water depth. Ibis $139,175-178$.

Schneider, D., Hunt Jr., G.L., Harrison, N.M., 1986. Mass and energy-transfer to seabirds in the Southeastern Bering Sea. Continental Shelf Research 5, 241-257.

Schneider, D., Harrison, N.M., Hunt Jr., G.L., 1987. Variation in the occurrence of marine birds at fronts in the Bering Sea. Estuarine, Coastal and Shelf Science 25, 135-141.

Sokal, R.R., 1978. Spatial autocorrelation in biology. I. Methodology. Biological Journal of the Linnean Society 10, 199-228. 
Spear, L.B., Ainley, D.G., 1997. Flight behaviour of seabirds in relation to wind direction and wing morphology. Ibis 139, 221-233.

Spear, L.B., Ainley, D.G., 1998. Morphological differences relative to ecological segregation in petrels (Family: Procellariidae) of the Southern Ocean and tropical Pacific. Auk 115, 1017-1033.

Spear, L.B., Ballance, L.T., Ainley, D.G., 2001. Response of seabirds to thermal boundaries in the tropical Pacific: the thermocline versus the Equatorial Front. Marine EcologyProgress Series 219, 275-289.

Spruzen, F.L., Woehler, E.J., 2002. The influence of synoptic weather patterns on the at-sea behaviour of three species of albatross. Polar Biology 25, 296-302.

Stahl, J.-C., Jouventin, P., Mougin, J.L., Roux, J.P., Weimerskirch, H., 1985. The foraging zones of seabirds in the Crozet Islands sector of the Southern Ocean. In: Siegfried, W.R., Condy, P.R., Laws, R.M. (Eds.), Antarctic Nutrient Cycles and Food Webs. Proceedings of the Fourth Symposium on Antarctic Biology. Springer, Berlin, pp. 478-486.

Sund, P.N., Blackburn, M., Williams, F., 1981. Tunas and their environment in the Pacific: a review. Oceanography and Marine Biology. An Annual Review 19, 443-512.

Surman, C.A., Wooller, R.D., 2000. Seabirds off the southwestern coast of Australia. Emu 100, 312-317.

Surman, C.A., Wooller, R.D., 2003. Comparative foraging ecology of five sympatric terns at a sub-tropical island in the eastern Indian Ocean. Journal of Zoology 259, 219-230.
Tynan, C.T., 1998. Ecological importance of the southern boundary of the Antarctic Circumpolar Current. Nature 392, 708-710.

van Franeker, J.A., 1994. A comparison of methods for counting seabirds at sea in the Southern Ocean. Journal of Field Ornithology 65, 96-108.

van Franeker, J.A., van den Brink, N.W., Bathmann, U.V., Pollard, R.T., de Barr, H.J.W., Wolff, W.J., 2002. Responses of seabirds, in particular prions (Pachyptila sp.), to smallscale processes in the Antarctic Polar Front. Deep-Sea Research II 49, 3931-3950.

Weimerskirch, H., Bartle, J.A., Jouventin, P., Stahl, J.C., 1988. Foraging ranges and partitioning of feeding zones in three species of southern albatrosses. Condor 90, 214-219.

Weimerskirch, H., Guionnet, T., Martin, J., Shaffer, S.A., Costa, D.P., Wilson, R.P., 2000. Fast and fuel efficient? Optimal use of wind by flying albatrosses. Proceedings of the Royal Society of London B 267, 1869-1874.

Weimerskirch, H., Le Corre, M., Jaquemet, S., Potier, M., Marsac, F., 2004. Foraging strategy of a top predator in tropical waters: Great Frigatebirds in the Mozambique Channel. Marine Ecology-Progress Series 275, 297-308.

Yen, P.P.W., Sydeman, W.J., Hyrenbach, K.D., 2004. Marine bird and cetacean associations with bathymetric habitats and shallow-water topographies: implications for trophic transfer and conservation. Journal of Marine Systems 50 (1-2), 79-99.

Zar, J.H., 1984. Biostatistical Analysis. Prentice-Hall, Englewood Cliffs, NJ. 